\title{
Digital native students' perceived competence on digital literacy: A study of digital native students at a private Islamic junior high boarding school
}

\author{
Nurul Alfia ${ }^{1}$, Sumardi², Diah Kristina ${ }^{3}$ \\ Universitas Sebelas Maret ${ }^{1,2,3}$ \\ 1Correspondence: nurulalfiao38@gmail.com
}

\begin{abstract}
The development of digital technology affects human life, especially for those born in the digital era (digital native). This can be seen from several aspects such as aspects of social life and learning styles that are different from previous generations. The digital native generation mostly spends most of their time on the internet, this naturally develops digital competencies. As a result, they are freely accessing information, whether related to academic interests or not, establish online relationships, play video games, and other exploration activities. Different results may be found in Private Islamic Junior High Boarding schools, where students are restricted from using gadgets. For this reason, the focus of this research is to find out the digital native students' perceived digital literacy competencies in a Private Islamic Junior High Boarding school used the case study. This research took 54 students of the Private Islamic Junior High Boarding schools in Surakarta with purposive sampling techniques. The results of this study revealed that students' photo-visual literacy, reproduction literacy, branching literacy, information literacy, socio-emotional thinking literacy, and the real-time thinking literacy were categorized as intermediate.
\end{abstract}

Keywords: digital native, students' perceived competence, digital literacy

\section{Introduction}

Recently, the developments of the Internet and digital technology have made it possible to access unlimited information anytime, anywhere, and by anyone. The exchange of information quickly and easily causes the use of the Internet grows every day. Based on digital annual report on online behaviour compiled by Kemp (2019a), around 57 percent of the total world population are now connected to the Internet network. The report revealed that Indonesia is the $5^{\text {th }}$ 
largest internet user with 150 million and active social media users with 150 million of the total population of $\mathbf{2 6 8 . 2}$ million, in which the number is clearly expected to continue to grow in the coming years (Kemp, 2019b). According to data compiled by APJII (Indonesian Internet Service Providers Association) in 2017 when viewed in terms of age, the largest number was shown by people aged 19 - 34, which amounted to $49.52 \%$, followed later by users with an age range between 13-18 years, 16.68\% (APJII, 2018). From these data it can be seen that internet users are dominated by the internet generation or commonly referred to as digital native. Digital native is a term that refers to those born and raised in the digital age. The ease of accessing and exchanging information allows anyone to create and spread fake information which contains lies (hoax) in order to achieve certain goals. Veil, Sellnow, Petrun (2012) explain that hoaxes are deliberately designed to damage public trust in an organization, product, service, or person. This means that hoaxes are very detrimental because they can damage the image of a person or an organization. Hoaxes can be categorized as cybercrime if they contain elements of violations as stipulated in the ITE Law and may be subject to criminal sanctions (Rifauddin \& Halida, 2018). Hoax is presented from mental attitudes that override integrity, especially hoaxes that appear in the name of religion.

The Internet today is more widely used to access social media in order to build relationships with other people. Sharing daily activities in the form of videos, photos, and statuses are something that teens often do when accessing social media accounts. A ton of criminal cases that occur due to the unwisely use of social media, ranging from cyber bullying, cybercrime, to sexual violence among teenagers (A'yuni, 2018). Livingstone (2008, p. 12 in Adityar, 2017) states that one of the causes of criminal behavior in cyber space is the limited ability of teenage internet literacy. Digital literacy is the ability of individuals to understand and use information from various digital sources (Gilster, 1997) including a large variety of complex cognitive, motor, sociological, and emotional skills, which users need in order to function effectively in digital environments (Hague \& Payton, 2010; Eshet-Alkalai, 2012). By having digital literacy competencies, students are expected more than just equipping oneself with the technical skills to operate digital devices, tools, software and hardware, and surfing the internet, but rather comprises a set of knowledge, competencies, and attitudes needed to become functional in a digital era (Ferrari, 2012). In other words, digital literacy is utilized as a students' guide and filter in accessing digital device in digital era.

Realizing the importance of having digital literacy competencies for adolescents, several prior studies have been carried out related to digital literacy competencies of students, as conducted by Ozdaman-Keskin, Ozata, \& Banar (2015) who measured Anadolu University students' digital literacy 
competencies and open learning and distance learning habits, it showed that most students only had basic competencies in digital literacy and the ability to use and process information and communication. In addition, Porat, Blau, \& Barak (2018) measured Junior-High School students' perceived competencies versus actual performance on digital literacy. The study revealed that only a few students had relevant perceived competence and actual performance. In general, students show high confidence in their digital literacy competence; however most of them have high perceived abilities but have low actual performance. Positive strong correlations were found between participants' selfreported evaluations of different digital skills, indicating their perception as a single factor, while actual performance tests revealed low- to medium-size correlations between different literacies. Today, in Indonesia the studies of digital literacy have been done by Amalia (2016) who examines the urgency of digital literacy for high school students: survey research on digital literacy level survey of state high school students in the special regions of Yogyakarta. From this research it can be seen that the level of digital literacy of state high school students in the Special Region of Yogyakarta is already at the advanced level. In addition, students are already proficient in using a variety of technological devices, have a very good critical understanding of internet content, such as being able to analyse, evaluate and synthesize content. Having and applying knowledge to netiquette who are good at interacting or communicating with others. Efforts to participate in the community using online social movements have also been carried out by some of them, although the results of the study show that most chose not to participate. On the other hand, A'yuni (2018) in her research on digital literacy in adolescents in the city of Surabaya revealed that the level of adolescent literacy based on aspects of internet searching, hyper textual navigation, and knowledge assembly was already high, but still had capabilities that were in the aspect of content evaluation. While, Sholihuddin (2014) examined the effect of individual competence on internet media literacy among students of the Bahrul 'Ulum Jombang Islamic boarding school, from this study it can be seen that the ability of media literacy (internet) among students of the Bahrul' Ulum Islamic Boarding School based on an average grade of ability is good, but based on European Commission standards, 2009 for technical skills and communicative abilities are at the basic stage, and critical understanding skills are at the medium level. As the prior studies reviewed shows, it can be concluded that most Indonesian digital native students belongs to medium level in digital literacy competence in form of technical skills.

Regarding the importance of digital literacy skills for students, the school began to pay attention to decrease the utilizing of technology in classroom and students' digital literacy, especially for modern boarding schools. Generally, the 
rules that are applied in public school allow the students to bring their personal smartphones or laptop (if needed) to the school environment. This allows them to spend more than 5 hours to interact with internet and digital devices. In contrast, private boarding-based school had been limiting their students on carrying their personal digital devices belongings and their interactions with internet due to its negative impacts which can be a distracter to the students. Although school's rule seems to limit their students' use of devices such as Smartphones and personal laptops; but they realize that digital development cannot be rejected and ignored, therefore to keep students closer to technological development and progress, schools begin to apply information technology in classroom learning but still control and guide students in accessing the internet, this is one of steps taken by the school to prevent cybercrime occurring among students. With the use and access of technology that is slightly limited from public school students, researchers are therefore interested in examining the digital literacy abilities of boarding-based school students in Surakarta.

As the prior studies reviewed show, most previous studies have raised the students' digital literacy in the form of their technical skills and communicative abilities of public school students, no previous study from issues of digital literacy competence in the field of education has measured private boarding school students' perceived competence on digital literacy, and only one study examined students' perceived competence on digital literacy versus real performance where the subject of the study was the public school students, not private boarding school students. Based on the framework of digital literacy suggested by Eshet-Alkalai (2012), the study examines the following research question: what is the digital native students' perceived competence on digital literacy?

\section{Literature review}

\section{Digital native}

Digital native is a term that refers to those who grow and develop surrounded by technology and the Internet. Prensky (2001, p. 1) describes digital native as those who grow and develop surrounded by technology; they spend most of their time using technology such as computers, video games, digital music players, video cameras, internet, smartphones, and other technological devices. Prensky also added that digital native spends on average 5 hours of time to connect with technology and the Internet. Meanwhile, according to Palfrey \& Gasser (2008, p. 1) digital native generation are those born after 1980, shortly after digital technology was released; they are able to use technology and spend 
most of their time accessing technology. In contrast, Teo (2013) states that digital native cannot only be defined by age or birth year, because not all teenagers born in the digital era are digital natives; a person can be said to be digital native if he has experience and spends much of his time interacting with technology, information, other people and institutions. Digital native has several characteristics (Prensky, 2001; Thompson, 2013):

a. Craving for speed and inability to tolerate slow-paced environment.

b. Have multitasking desires and needs.

c. Tendency to understand illustrations than text

d. Preference for learning through activities and practices rather than reading or listening.

e. Preference for process information with nonlinear ways

f. Preference for networking and collaborating.

g. Mixing of work and play

h. Preference for fantasy context as found in games and realistic TV and movies.

i. They feels difficult and uncomfortable without technology, because technology become part of their life

j. Want to get benefits / rewards immediately (instant).

Based on the above characteristics, teenagers today can be said as digital native; because in addition to being able to master technology in a short time, they are able to spend most of their time accessing the internet and are prefer to something instant.

In addition, digital native generations in educational settings are assumed have a high level of digital literacy, it enables them to be comfortable with utilizing digital technologies and to adopt the new or unfamiliar technologies easily (Ng, 2012). Moreover, Porat, Blau, \& Barak (2018) claimed that digital natives, born and grow surrounded by digital devices and are connected through social network, will naturally develop their digital literacy competencies. In regards with it, Nugroho (as cited in Haryanto, 2019) stated that Indonesian youth users of internet already possess the advanced level of digital literacy competencies, but they got the competencies by self-taught.

The prior studies indicate that digital native generation are naturally have digital literacy competence at least technical competence, these statements are reinforced by the phenomenon that occurs in the field where a lot of early children who master the use of smartphone and accessing internet and social media easily. Meanwhile, the cognitive skills of digital native students need to dig in deeper. 


\section{Students' perceived competence}

Based on Tang, Addison, La Sure Bryant, Norman, O'Connell, \& StewartSicking, 2004 (as cited in Flasch, Taylor, Clauber, \& Robinson, 2017) selfperceived competence and comfort may be described as self-efficacy and refers to feelings or beliefs about one's ability to succeed at a given task or with a specific skill. Self-perceived employability is a current assessment of one's capacity to navigate the world of work in the future (especially short-term), whereas subjective career success reflects current evaluation of an accumulation of past experiences. Meanwhile, Wilkinson (2009) defined self-perceived competence/Self-perceptions as an individual's beliefs about their abilities and performance in broad academic areas. All things considered, self-perceived competence may be defined as a person's beliefs about their ability to succeed in a specific performance in academic areas.

\section{Digital literacy}

At the beginning of its appearance, literacy was interpreted as the ability to read and write, but in its development literacy was interpreted as cognitive abilities related to reading and writing abilities (UNESCO, 2005), while Alberta Education (2015) stated that literacy was the ability, confidence, and will to engage in using language to acquire and communicate meaning in all aspects of daily life. Meanwhile, Pilgrim \& Martinez (2013) defines literacy as the ability to read and write effectively in various media. Along with the development of digital technology, the term literacy then develops to become more widespread so that the term digital literacy emerges. Digital literacy was first introduced by Paul Gilster in 1997 in his book "Digital Literacy". According to Gilster (1997), digital literacy is the ability to understand and use information obtained from various digital sources. Meanwhile, Martin (2005 p. 135) states that digital literacy is the ability, attitude, and awareness of someone in using digital devices to identify, access, manage, integrate, evaluate, analyze, and process information, build new knowledge, create media expressions, and communicate with others appropriately. In addition, Eshet-Alkalai (2012) states that digital literacy is not only limited to the ability to use technological devices, but also the ability to master cognitive, motoric, sociological, and emotional abilities. Slightly different from previous research, the framework that was conceived by Eshet-Alkalai integrates cognitive abilities, thinking strategies, and mind-set in the use of technology. The cognitive abilities, thought strategies, and thought patterns referred to are:

1. Photo-visual thinking: the ability to get information presented visually through pictures, icons, graphics, charts, and so on 
2. Reproduction thinking: the ability to create new meanings and interpret information obtained from digital sources that already exist.

3. Informational thinking: the ability to analyse information critically about the credibility and quality of information obtained through digital devices

4. Branched thinking: the ability to synthesize knowledge and understand information through non-linear navigation in a hypertensive environment, and maintain focus without being "lost" in cyberspace.

5. Social-emotional thinking: the ability to extract useful information from digital communication, sharing information, exchanging insights, emotional expressions, and projecting one's online personality, while avoiding online risks that might occur.

6. Real-time thinking: the ability to effectively process stimuli and information simultaneously at high speed in a digital environment, such as learning simulations, online games, or synchronous online teaching and learning.

To be digitally literate, students have to possess not only technical and operational skills of digital but also the cognitive competencies. The indicators proposed by Eshet and Alkalai (2012) cover most of the cognitive abilities that students employ while working in digital environment (Porat, Blau, \& Barak, 2018), so it is assumed that Eshet-Alkalai framework are suitable for this kind of research.

\section{Method}

\section{Participants}

The participants of the study were 54 students of the eighth grade in an Islamic private high school (around 14 years old). Students came from a variety of backgrounds that are spread geographically in Surakarta. All participants are female students. Thus, these young learners are considered "digital natives" (Prensky, 2001) and as such, on average, are expected to have relatively high skills in the use of digital technology. No one of the participants in the class is allowed to bring a smartphone or laptop, in this case only teachers have access to a computer that is connected to the internet and can be used to project digital content and digital textbooks on the projector screen. Students who participated in this study only had occasional access to computer labs and the internet and were rarely connected to Smartphone and the internet due to school policies. 


\section{Procedure}

This research belongs to case study research with qualitative approach. The case study is to explore in-depth a phenomenon that happened in a certain circumstance through detailed data collection involving multiple sources of information, such as observations, interviews, audio-visual materials, and documents (Creswell, 2007, p. 73). Along with Creswell's definition before, this study employs a qualitative case study to reveal the self-perceived competence of digital literacy of digital native students in private junior high school.

\section{Data collection}

Based on Creswell (2007, p. 73) there are several techniques of data collection; observation, interviews, audio-visual materials, questionnaires, and documents. In this case, the researcher utilized close-ended questionnaire technique and Guttman scale to collect the information about students' perceived competence on digital literacy and held an interview with the teacher as supporting data. The participants are allocated 30 minutes to fill out the digital literacy competency questionnaire. However, if students request additional time to complete an assignment there will be a time extension given. The result of the data will be displayed as percentage with descriptive qualitative explanation.

\section{Data analysis}

According to Miles and Huberman (1994) there are three steps to analyse data, reducing the data, displaying the data, and drawing conclusion. In the beginning, the data relating to the research will be processed, while other findings that are not related will be discarded. In this study, the processed data is data obtained from a questionnaire about students' perceived competence on digital literacy. Furthermore, as for the scoring calculation of respondents on the Guttman scale is 1 for the YES response, and o for the NO response. The questionnaires will be adapted from Porat, Blau, \& Barak (2018) based on Eshet-Alkalai's (2012) with 28 items in total, in details 8 items of photo-visual competence, 4 items of reproduction competence, 3 items of branching competence, 4 items of information competence, 6 items of social-emotional competence, and 3 items of real time thinking competence.

\section{Findings}

This study use Guttman scale to measure digital native students' perceived competence on digital literacy. Regarding to the questionnaire given, the following data were obtained: 
Table.1 The percentage of digital native students' perceived competence on DL

\begin{tabular}{lll}
\hline No & Aspects & Percentage \\
\hline 1 & Photo-visual & $85.87 \%$ \\
2 & Reproduction & $52.31 \%$ \\
3 & Branching & $59.25 \%$ \\
4 & Information & $77.77 \%$ \\
5 & Socio-emotional & $79.01 \%$ \\
& Real-time & \\
6 & thinking & $58.62 \%$ \\
\hline
\end{tabular}

After serving as a percentage, the next step was to describe and draw conclusions about each aspect, as follows:

Table.2 Interpretation of students' self-perceived competence scores (Iskani, 2014)

\begin{tabular}{l|l}
\hline Percentage & Criteria \\
\hline $0 \%$ & Very Low \\
$10 \%-49 \%$ & Low \\
$50 \%$ & Standard \\
$51 \%-99 \%$ & Intermediate \\
$100 \%$ & Advanced \\
\hline
\end{tabular}

Table 2 is utilized as a guidance to determine the level of students' perceived competence on digital literacy. Regarding the results of the questionnaire, it can be seen that digital natives have highest score in photovisual that as much as $85.87 \%$, and has quite satisfactory results in the aspect of reproduction, which was as much as $52 \%$. But in total, students' self-perceived competence was already at intermediate level in all aspects of digital literacy competence both in technical skills and cognitive skills.

\section{Discussion}

The purpose of the study was to explore digital native students' competence on digital literacy especially the private Islamic boarding school students. EshetAlkalai (2012) suggested that to survive in digital era, except to having technical skills pupil must also have cognitive abilities such as the ability to think critically and creatively. The cognitive abilities proposed by Eshet-Alkalai (2012) include: photo-visual, reproduction, branching, information, social-emotional, and real-time thinking. The content analysis of the close-ended questionnaires 
revealed that generally, boarding school students' perceived competencies belonged to the advanced level of digital literacy, especially in photo-visual aspect which reached greatest score among others aspects. In detailed, students' perceived competence on digital literacy can be seen as follows:

\section{Photo-visual}

Photo-visual competence represents the ability to read and interpret information displayed in charts, icons, graphs, pictures, maps, etc. (EshetAlkalai, 2012). The result of the questionnaires given in Table 2, showed that photo-visual aspect got the highest score, it means that most of students were able to interpret information presented by illustrations. According to EshetAlkalai (2004), this was due to students applying the Synchronic Literacy to interpret the information they obtained through illustration. Synchronic literacy refers to the ability to synchronize images or illustration presented with the appropriate word or purpose.

\section{Reproduction}

Reproduction competence refers to the ability to recreate new information based on the existing information (Eshet-Alkalai, 2012). Based on the questionnaire given, even though it revealed that this aspect reached the lowest score among others, but most of students were creative. They were able to create new product based on the existing one but unfortunately they did not list the sources of information into their projects. Moreover, they did not know where the information is belonging to.

\section{Branching}

Branching competence help the students' to navigate their way through a complex website with many web pages without getting lost. In other words, branching can reduce the possibility to being distracted on what they looked for. Regarding to the result, it can be seen that more than a half participants were confident that they were not able to getting lost, in the use of social media or blogs for example, students utilize the Hashtag feature to find or upload certain posts that suitable to the criteria of information. The students' perceived competence of this aspects was categorized as intermediate, with $59.25 \%$

\section{Information}

This competence is related to students' critical thinking skill. The ease of accessing and exchanging information allows anyone to create and spread fake information which contains lies (hoax) in order to achieve certain goal. From 
the amount of information available on the internet, hoaxes are the things that are most often found. Therefore, through information competencies (literacy) the students are expected to be able to find, identify, analyse, and select the suitable information. Checking the accuracy of information obtained by comparing information from other sources is a mandatory thing students must do before quoting or sharing information. Regarding on the result of closeended questionnaire, it shown that students' perceived competence in information literacy were in advanced level. It means that almost all students were able to distinguish which information is fake and which information can be trusted. This result indirectly also reveal that students' possess high critical thinking skill.

\section{Social-Emotional}

In social-emotional literacy, the students are required to be careful not to share personal information about self, friends, and families through social media or another person. It does not stop there; the students have to pay attention about what they would post in cyberspace, respecting others' opinion in email, forum, chat room, etc. is one of parts in social-emotional literacy. Based on the result, according to the results of the questionnaire calculation, the ability of students in social-emotional aspects of literacy is at the advanced level of around 79.01\%. It means that students' awareness not to share personal information in social media was high.

\section{Real-Time Thinking}

Referring to the result of the questionnaires, most students cannot deny pop up message or even pop up advertisement while searching for information. The students tend to open and reply the messages due to messages and ads were more attractive than information they looked for. However, students' perceived competence in the aspect of real-time thinking was still at the intermediate level, with percentage at $58.62 \%$.

Whereas cognitive abilities especially information literacy that were possessed by the students inseparable from the student environment and the influence of the teacher. Based on an interview with one of the teachers, she said that there was often an exchange of information between the teacher and students. When students get new information from the internet, they will discuss it with the teacher they think they are close with (in this case the English teacher). Then the teacher will allow students to take the information if it was considered good, and ask students to leave the information if it was considered bad. 
The students these days often were having discussion with their teacher, especially with me. They came with something new in their mind, for example they came with a new song then told me "Miss, I found a good song, what do you think about the lyrics?" If I think it is not suitable for them I will tell them "Oh that song are not suitable for you, the meaning is not good." Due to our limited meeting time in class, sometimes they found the meaning of the lyric by themselves using manual dictionary." Meanwhile, the influence of the environment can be seen from the environment in which students are located, based on an interview with one of teachers it revealed that students spend a lot of time in the dorm which teaches a lot of good values based on religious values. These values may influence their attitude through social media and internet.

\section{Conclusion}

Regarding to the close-ended questionnaires, it can be seen that digital native students' perceived competence in digital literacy especially in boarding school students based on aspects photo-visual literacy was categorized as advanced level with highest percentage at $85.87 \%$, meanwhile in the aspects of creating new information based on the existing one (reproduction literacy); students' competence percentage was $52.31 \%$ at intermediate level. In addition, branching aspect at intermediate level with percentage score was 59.25\%. For the selecting suitable information ability and avoiding hoaxes (information), the level of students' competence at advanced level with percentage at $77.77 \%$. For the awareness of sharing and posting in social media (socio-emotional thinking) at advanced level with $79.01 \%$. While the real-time thinking literacy at intermediate level, with $58.62 \%$.

Based on the explanation above, it can be concluded that the limitations of accessing digital devices and the Internet are not a barrier for digital native students to have qualified literacy skills. As a generation who born in the digital age, making digital native able to master technical skills in a self-taught, this is supported by the statement of Nugroho, Head of Siberkreasi Research Division in an interview (as cited by Haryanto, 2019) which stated that the literacy skills of Indonesian youth are already at level 3 (advanced) but most of the results were self-taught. This statement was based on research conducted by Siberkreasi from September to November 2018 which involved 2,000 respondents ranging in age from 13-18 years in four cities namely Bandung, Denpasar, Pontianak and Surabaya. In addition, the students' cognitive abilities cannot be separated from the enviromental influences, where the environment in which students live tends to teach positive values based on religious values, so that more or less these values affect the attitude of students in using social 
media. In addition, the research on the influence of values from the environment has not been proven authentically, so it needs further research.

\section{References}

Adityar (2017). Pengaruh literasi digital terhadap perilaku internet beresiko di kalangan siswa SMA dan MA di Kota Makassar. Thesis: Universitas Hasanuddin. Makassar

Alberta Education. (2015). What is literacy? Retrieved from https://education.alberta.ca/literacy-and numeracy/literacy/everyone/what-is-literacy/

Amalia, R.R. (2016). Urgensi literasi digital untuk pelajar SMA: Penelitian survei tingkat literasi digital pelajar sekolah menengah atas negeri di Daerah Istimewa Yogyakarta. Skripsi: Universitas Gadjah Mada. Yogyakarta.

A'yuni. Q.Q. (2018). Literasi digital remaja di Kota Surabaya. Universitas Airlangga Surabaya

Creswell, John W. (2007). Qualitative inquiry \& research design: Choosing among five approaches. London: SAGE Publication.

Eshet-Alkalai, Y. (2004). Digital literacy: A conceptual framework for survival skills in the digital era. Journal of Educational Multimedia and Hypermedia. 13.

Eshet-Alkalai, Y. (2012). Thinking in the digital era: A revised model for digital literacy. Issues in Informing Science and Information Technology, 9, 267-276.

Ferrari, A. (2012). Digital competence in practice: An analysis of frameworks. Luxembourg: Publications Office of the European Union: JRC IPTS. DOI: $10.2791 / 82116$.

Flasch, P; Taylor, D; Claubber, R.N; Robinson, E. (2017). Examining students' self-perceived competence and comfort in an experiential play therapy counseling course: A single group pretest-posttest investigation. International Journal for the Scholarship of Teaching and Learning, 11(1).

Gilster, P. (1997). Digital literacy. N.Y: Wiley Computer Publishing.

Global Education Monitoring Report Team UNESCO. (2005). Education for All Global Monitoring Report: Literacy. Retrieved from https://unesdoc.unesco.org/ark:/48223/pfooo0141639

Hague, C., \& Payton, S. (2010). Digital literacy across the curriculum. UK: Futurelab.

Haryanto, A.T.(2019). 'Literasi digital remaja RI kebanyakan hasil otodidak'. Detikinet. Retrieved from https://inet.detik.com/cyberlife/d4492896/literasi-digital-remaja-ri-kebanyakan-hasil-otodidak

Iskani. (2014). Pengukuran skala guttman secara tradisional (cross sectional). Retrieved from http://ejournal.poltektegal.ac.id/index.php/informatika/article/downloa dSuppFile/832/345 
Kemp, S. (2019a). Special reports digital 2019: Global internet use accelerates [Blog Post]. $\quad$ Retrieved https://wearesocial.com/blog/2019/o1/digital-2019-global-internet-useaccelerates

Kemp, S. (2019b). Hootsuite (We are Social): Indonesian Digital Report 2019. Retrieved from https://datareportal.com/reports/digital-2019-indonesia

Martin, A. (2005). DigEuLit-A European framework for digital literacy: A progress report. Journal of eLiteracy, 2(2), 130-136.

Miles, M. B., \& Huberman, A. M. (1994). Qualitative data analysis: A sourcebook. Thousand Oaks, CA: Sage.

$\mathrm{Ng}$, W. (2012). Can we teach digital natives digital literacy? Computers \& Education. https://doi.org/10.1016/j.compedu.2012.04.016

Ozdaman-Keskin, N. Ozata, F.Z \& Banar, K (2015). Examining digital literacy competences and learning habits of open and distance learners. Contemporary Educational Technology. 55, 1321-1335.

Palfrey, J., \& Gasser, U. (2008). Born digital: Understanding the first generation of digital natives. New York, NY: Basic Books.

Pilgrim,J \& Martinez, E, E. (2013). Defining literacy in the 21st century: a guide to terminology and skills. Texas Journal of Literacy Education,1(1)

Porat E., Blau I. \& Barak A. (2018). Measuring digital literacies: Junior highschool students' perceived competencies versus actual performance, Computers \& Education, DOI: 10.1016/j.compedu.2018.06.030

Prensky, M. (2001). Digital natives, digital immigrants. India: MCB University Press

Rifauddin, M., Halida, A. N. (2018). Waspada cybercrime dan informasi hoax padamedia sosial facebook. Khizanah al-Hikmah :Jurnal Ilmu Perpustakaan, Informasi, dan Kearsipan. 6(2),98-111. DOI: 10.24252/kah.v6i2a2

Sholihuddin, M. (2014). Pengaruh kompetensi individu (individual competence) terhadap literasi media internet di kalangan santri (Studi eksplanatif tentang pengaruh technical skills, critical understanding dan communicative abilities terhadap literasi media internet di kalangan. (Skripsi) Retrieved from http://repository.unair.ac.id/16297/

Teo, T. (2013). An initial development and validation of a digital natives assessment scale (DNAS). Computers \& Education. https://doi.org/10.1016/j.compedu.2013.02.012

Thompson, P. (2013). The digital natives as learners: Technology use patterns and approaches to learning. Computers \& Education. https://doi.org/10.1016/j.compedu.2012.12.022

Tim APJII. (2018). Buletin APJII Ed. 22 Maret 2018. Jakarta: APJII.

Veil, S. R., Sellnow, T. L., Petrun, E. L., 2012. Hoaxes and the paradoxical challenges of restoring legitimacy: Dominos' response to its YouTube crisis. Management Communication Quarterly, 26(2), 322-345

Wilkinson, A. (2009). Academic self-perceptions of elementary school children. Retrieved from AcadSelfPercept. htm on 15th August. 